\title{
The Correlation Between Academic Supervision by School Supervisors and Principals with the Ability of Biology Teachers to Design HOTS Items
}

\author{
Iis Nurhayati ${ }^{1}$, Hari Setiadi ${ }^{1}$, Abdul Rahman A. Ghani ${ }^{1}$.Ernawati ${ }^{1, *}$ \\ ${ }^{1}$ Sekolah Pascasarjana, Universitas Muhammadiyah Prof. DR. HAMKA Jakarta, Indonesia
}

*Corresponding author: ernawati.pep@uhamka.ac.id

\begin{abstract}
This study aims to analyze the correlation of academic supervision carried out by school supervisors and principals on the ability of biology teachers to design HOTS items. The research method is a survey method with corrective techniques. In this study, the data collection technique was carried out by distributing instruments that had been tested for their validity and reliability beforehand, while the sample of this study was carried out to a number of teachers who were members of the Senior High School Biology Subject Teacher Conference in South Tangerang City. Data analysis techniques obtained through analysis of normality test, data quality test (validity and reliability), regression assumption test, linearity test, and coefficient of determination. The results of the study based on the significant test obtained the correlation coefficient of the academic supervision variable by the supervisor $\left(\mathrm{X}_{1}\right)$ and the teacher's ability to design HOTS items (Y) of 0.091 which was significant at 0.632 . Furthermore, the correlation coefficient of the variable of academic supervision by the principal $\left(\mathrm{X}_{2}\right)$ and the teacher's ability to compose HOTS items $(\mathrm{Y})$ is 0.021 which is significant at 0.912 , and the correlation coefficient between the variable of academic supervision by the principal $\left(\mathrm{X}_{2}\right)$ and the variable teacher's ability to design HOTS items (Y) is 0.021 which is significant at 0.912 . Therefore, based on the closeness of the relationship between the dependent variable and the independent variable is weak category because $r<0.5$. This shows that in this study the ability of a biology teacher to design HOTS Items was not influenced by academic supervision carried out the supervisor or the principal (1\%), but by other variables (99\%).
\end{abstract}

Keywords: Academic Supervision, School Supervisor, Principal, HOTS.

\section{INTRODUCTION}

The principal is the main power holder in the school, so it is necessary for the principal to be able to understand well the principal's leadership and supervision management, this is because the principal's leadership and supervision are two things that are related and strengthen one another. Principals and teachers have a very important role in the implementation of education, because school principals and teachers directly interact with students when the teaching and learning process takes place. Therefore, a school principal needs to guide, guide and guide the teachers and staff properly. The teacher in carrying out his daily duties in class is a single player. With a high commitment and professional spirit can guide and guide teachers to work professionally according to the rules. However, in Indonesia it is very difficult to liberate teachers too much in teaching students in class. The teacher needs to be supervised 
by the principal in order to increase their professionalism and performance in teaching students in class. Through this supervision, it is also hoped that the principal will control and guarantee the quality of learning in the classroom [1].

Educational supervision is aimed at efforts to improve the teaching and learning situation which is meant by the teaching and learning process here is a situation where the interaction process occurs between educators and students in an effort to achieve optimal goals. The quality of learning is strongly influenced by the professional quality of the performance of the teaching staff, therefore efforts to improve the professional ability of teaching staff in carrying out the learning and teaching process through supervision assistance, need to continuously get attention and professional assistance from the person in charge of education. When the implementation of supervision is carried out intensively by the head of madrasah, not only the quality of the teaching and learning process increases, but the competence of educators can also increase. This quality can improve excellent educational services to students as consumers of education [2].

Mukhtar stated that academic supervision is supervision that focuses on observations during the academic period that are directly within the scope of learning activities carried out by teachers to help students while in the learning process. The substantial thing that exists in the school organization is learning to direct, guide and foster teachers in carrying out a quality learning process by holding academic supervision carried out by school supervisors. The improvement of the teaching and learning process must be carried out continuously and continuously. This is done to produce quality educational output. One of the steps that school supervisors must take is to provide academic supervision. Academic supervision is a series of activities to help teachers develop their ability to manage the learning process in order to achieve learning objectives. It can be concluded that academic supervision is the activity of providing to assistance to teachers in order to assist teachers in the learning process which consists of planning, implementing and assessing learning in order to achieve the planned goals. Therefore, academic supervision provides services and assistance to teachers to improve the quality of the learning process. Academic supervision is not for finding mistakes of teachers, but is aimed at improving and improving the quality of learning [3]

The main target of supervision is the ability of teachers to plan / prepare learning activities, carry out learning activities, assess learning outcomes, take advantage of assessment results to improve learning services, create a pleasant learning environment, take advantage of available learning resources, and develop learning interactions between students and teachers. (strategy, method, technique) right. Supervision is expected to improve the quality of learning, students will be well served to improve their abilities according to their potential, and increase achievement and the percentage of graduates from educational institutions [4].

Supervision is an effort to provide services to teachers both individually and in groups, with the aim of improving teaching, including stimulating, selecting job growth and teacher development as well as revising educational goals, teaching materials and teaching methods and evaluation. What is meant by supervisor is a person who plays a role in providing assistance to teachers by stimulating teachers to maintain a better teaching and learning atmosphere [5]. From the educational side, it can be understood that education supervision is an effort and / or service to provide coaching assistance provided by supervisors to teachers in an effort to improve the quality of learning. The principal is the supervisor for the teachers. He plays an important role in helping teachers to improve their abilities and professionalism. However, although several principals in their capacity as supervisors have made efforts to carry out their duties and responsibilities in supervision of teachers, the results are still far from expected. [6].

Regarding the ability of students' scientific process which needs to be evaluated in the future to improve higher-order thinking skills. Biology which is a branch of science and is closely related to real life. So that higher-order thinking skills need to be trained and applied in the implementation of biology learning so that students can develop cognitive abilities with a more critical, active, creative, and innovative mindset [7].

The average HOTS category items in the Biology UN for the 2014-2016 academic year were 29.16\%, with details of the percentage per year respectively $32.5 \%, 30 \%$, and $25 \%$. These findings show that the percentage of HOTS characteristics on the Biology UN 
item is relatively low each year. So that it can be traced in practice, the application of HOTS learning is not an easy thing to implement and apply at the national level (UN) let alone be applied by teachers [8]. The problem that occurs in science subjects is the weakness of the learning process, where students are often not encouraged to find knowledge themselves, but students are asked to remember, so as a result students cannot provide solutions to problems related to Science [9].

So that in learning, the teacher must really master the material and learning strategies and the teacher is also faced with challenges with the environment and internal students he teaches. Learning strategies are very important in implementing students' higher thinking skills because HOTS learning is learning that prioritizes students to be able to find the benefits of learning a material on their own, and also as we care, we can care more about learning abilities and learning styles that suit students because sometimes teachers already felt that they were doing their best so that learning activities were interesting, but the responses of the students were still cool, and relatively passive [10].

High Order Thinking Skills is a thinking process of students at a higher cognitive level that is developed from various cognitive concepts and methods and learning taxonomies such as problem solving methods, bloom taxonomies, and taxonomies of learning, teaching, and assessment. These high order thinking skills include problem-solving skills, creative thinking skills, critical thinking skills, argumentation skills, and decision-making abilities. According to King, high order thinking skills include critical, logical, reflective, metacognitive, and creative thinking, while according to Newman and Wehlage, with high order thinking students will be able to clearly distinguish ideas or ideas, argue well, be able to solve problems, able to construct explanations, able to hypothesize and understand complex matters more clearly. According to Vui, high order thinking skills will occur when a person associates new information with information that is already stored in his / her memory and links it and / or rearranges and develops that information to achieve a goal or find a solution to a situation that is difficult to solve [11].

The Australian Council for Educational Research states that higher-order thinking skills are processes: analyzing, reflecting, providing arguments (reasons), applying concepts to different situations, constructing, creating. Higher order thinking skills are not just the ability to remember, know, or repeat. Higher order thinking skills include the ability to solve problems (problem solving), critical thinking skills, creative thinking, reasoning skills, and decision making skills [12]. There are two characteristics that underlie higherorder thinking skills, namely critical and creative thinking. From some of the experts above, higherorder thinking skills are a process of deep and broad thinking skills that involve critical and creative processing of information in dealing with and solving complex problems and involving analyzing, evaluating and creating skills [13]. Higher Order Thinking Skill (HOTS) or higher order thinking skills are skills of connecting ideas and facts, analyzing, explaining, hypothesizing, synthesizing or arriving at the stage of concluding to solve problems. Furthermore, it was emphasized that "HOTS activities can help skilled students seek knowledge in inductive and deductive reasoning to think about answers or identify and explore from a lesson" [14]

HOTS items generally measure the Knowledge Dimension at the metacognitive level (the other dimensions are factual, conceptual, and procedural). The metacognitive dimension is the ability to connect several different concepts, interpret, solve problems (problem solving), discover new concepts (discover new concepts), reason / argue (reasoning), and make the right decisions. In addition, HOTS items also indicate the Cognitive Dimensions at the C4-C6 level, where the cognitive dimensions consist of: knowing (C1), understanding (C2), applying (C3), analyzing (C4), evaluating (C5), and creating (C5). Operational Verbs at each level of the cognitive dimension are not a measure of whether the question is HOTS or not. For example, $\mathrm{KKO}$ 'determines' is $\mathrm{KKO}$ for domains $\mathrm{C} 2$ and $\mathrm{C} 3$, but $\mathrm{KKO}$ 'determines' can become the domain of C5 (evaluating) if students are asked to make decisions that begin with the process of analyzing the information presented in the stimulus, then students use the results of the analysis process to answer items [15]

\section{METHODS}

The research method used is through a survey method with corrective techniques. In this study, data collection techniques were carried out by distributing 
instruments that had been tested for their validity and reliability beforehand, while the following was related to the number of valid items for each independent variable and fixed variable instrument.

The instrument in this study consisted of three instruments from each variable consisting of $\mathrm{X} 1$ (Academic Supervision by School Supervisors) and X2 (Academic Supervision by the Principal) with 24 statement items each, then the $\mathrm{Y}$ variable (Teacher Ability to Compose About HOTS) there are 6 points of statement.

The population in this study were all SMA in the South Tangerang City area. Based on this population, a sample of 61 high school biology teachers in the city of South Tangerang was obtained. Then the sample was divided into two categories including 30 biology teachers as a sample trial (control sample) and 30 other teachers as the sample studied (experimental sample). The sampling technique is through the random sampling technique (randomly).

\section{RESULTS AND DISCUSSION}

The identification of the description of the research respondents by gender consisted of 5 people or $17 \%$, while the female respondents were 25 people or $83 \%$. Then based on the educator certificate consisting of 19 people or $63 \%$, the number of respondents who had a certificate of teacher in science subjects (Physics, Chemistry, or Science on Junior High School/Vocational High School) amounted to 3 people or $10 \%$, while respondents who did not have the Certificate of Educators amounted of 8 people or $27 \%$.

The identification based on school assignments, namely 13 people or $43.3 \%$ served in public schools, while the respondents who served in private schools were 17 people or $56.7 \%$. Then based on graduates, the majority of respondents $(63.33 \%)$ have the latest academic/educational qualifications $\mathrm{S} 1$ and/or $\mathrm{S} 2$ majoring (Magister) in Biology. Respondents with the latest academic/educational qualifications of undergraduate and/or postgraduate students not majoring in Biology in the Natural Sciences category were 10 people or $33.33 \%$, while respondents who were not Department of Biology and not Department of Natural Sciences were only 1 person or $3.33 \%$.

\subsection{Normality Test Results}

The results of the normality test with the SPSS 19.0 for Windows program are as follows: the KolmogorovSmirnov (KS) value for the academic supervision variable by supervisors is 0.731 with a significance probability of 0.660 and the value is above 0.05 , this means that the data on the variable of academic supervision by supervisors is distributed equally normal. Likewise, the $\mathrm{K}-\mathrm{S}$ value of the academic supervision variable by the principal was 0.769 with a significance probability of 0.596 and the teacher's ability variable in compiling HOTS items was 0.473 with a significance probability of 0.979 .

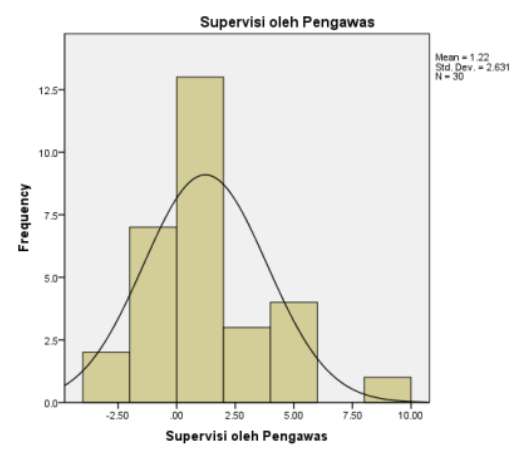

Figure 1. The histogram of normal curve of data for academic supervision by school supervisors 


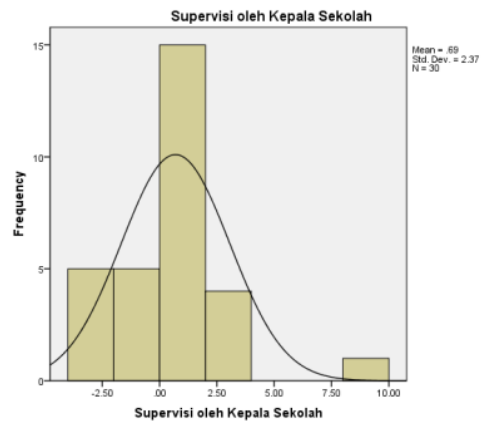

Figure 2. The Histogram of normal curve of data for academic supervision by the principal

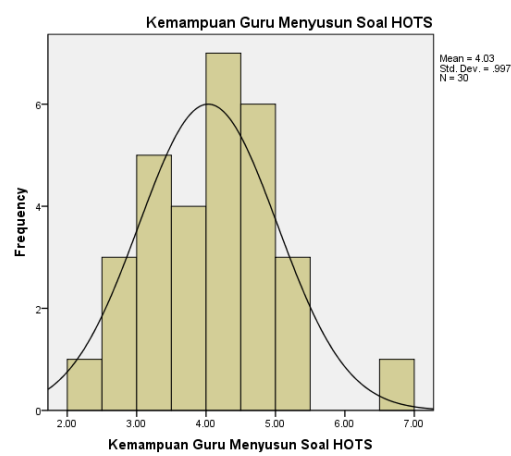

Figure 3. The histogram of normal curve of the teacher's ability to compile HOTS items

The histogram in the following figure shows that for each variable in this study the curve is normally almost symmetrical and statistically it has been proven that the data is normally distributed. Based on the results of the normality test, the results show that all of the research variables are normally distributed, so the statistical test in this study is parametric testing.

The results of data analysis of 30 respondents obtained data with the following description

\begin{tabular}{|l|r|r|r|}
\hline & \multicolumn{1}{|c|}{ Statistics } \\
& $\begin{array}{c}\text { Supervisi oleh } \\
\text { Pengawas }\end{array}$ & $\begin{array}{c}\text { Supervisi oleh } \\
\text { Kepala } \\
\text { Sekolah }\end{array}$ & $\begin{array}{c}\text { Kemampuan } \\
\text { Guru } \\
\text { Menyusun } \\
\text { Soal HOTS }\end{array}$ \\
\hline $\mathrm{N} \quad$ Valid & 30 & 30 & 30 \\
Mean & 0 & 0 & 0 \\
Median & 1.2240 & .6947 & 4.0307 \\
Mode & 1.0500 & .7200 & 4.1400 \\
Std. Deviation & 1.89 & 1.64 & $2.08^{\mathrm{a}}$ \\
Variance & 2.63118 & 2.36977 & .99724 \\
Skewness & 6.923 & 5.616 & .994 \\
Std. Error of Skewness & .807 & .787 & .332 \\
Kurtosis & .427 & .427 & .427 \\
Std. Error of Kurtosis & 1.190 & 2.967 & .728 \\
Range & .833 & .833 & .833 \\
Minimum & 12.10 & 11.93 & 4.72 \\
Maximum & -3.18 & -3.46 & 2.08 \\
\hline
\end{tabular}

Table 1. Table Description of Research Data

Based on the description of the following table, the data can be decomposed:
The variable of academic supervision by supervisors $\left(\mathrm{X}_{1}\right)$ obtained a range of 12.10 ; the lowest 
value (min) was -3.18 , the highest value (max) was 8.92; an average (mean) of 1.224 with a standard deviation of 2.631; the data distribution rate (variance) was 6,923; The skewness value of the data is 0.807 and the peak size of the data distribution (kurtosis) is 1.190.

The academic supervision variable by the principal $\left(\mathrm{X}_{2}\right)$ obtained a range of 11.93 ; the lowest value (min) of -3.46; the highest value ( $\max$ ) of 8.47 ; an average (mean) of 0.695 with a standard deviation of 2.370 ; the level of data distribution (variance) of 5,616; The skewness value of the data is 0.787 and the peak size of the data distribution (kurtosis) is 2.967.

The variable of the teacher's ability in designing HOTS items (Y) obtained a range of 4.72; the lowest value ( $\min$ ) of 2.08; the highest value ( $\max$ ) of 6.80 ; the average (mean) of 4.03 with a standard deviation of 0.997; the level of data distribution (variance) of
0.994; the skewness value of the data (skewness) is 0.332 and the peak size of the data distribution (kurtosis) is 0.728 .

\subsection{Multicollinearity Test Results}

Through the analysis, the results obtained from the SPSS output, the tolerance value shows that there are no independent variables that have a tolerance value less than 0.10 , which means that there is no correlation between the independent variables whose value is more than $95 \%$. The results of the calculation of the Variance Inflation Factor (VIF) value also show that there is not one independent variable that has a VIF value of more than 10 , so it can be concluded that there is no multicollinearity between the independent variables in the regression model

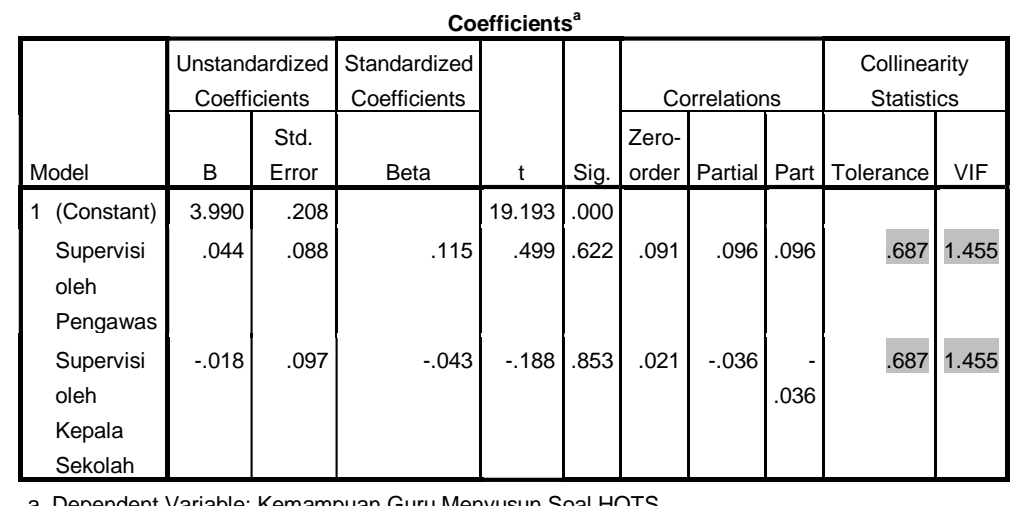

Table 2. Table of Multicollinearity Test Results

\subsection{Autocorrelation Test Results}

The autocorrelation symptom test was carried out by looking at the results of the Durbin-Watson (D-W) whose value was 1,860 . With a significance of $0.05, \mathrm{k}$ (regressor) $=3$ and $n$ (observation) $=30$ the value of $\mathrm{dL}=1.284$ was obtained while the value of $\mathrm{dU}=1.567$. because D-W 1,860 is between dU and (4-dU), it can be concluded that there is no autocorrelation, this means that the regression model produced in this study is free from autocorrelation.

\subsection{Linearity Test Results}

The linearity coefficient is seen in the ANOVA Table row Deviation from Linearity, respectively, namely Sig. $=0.978$ and Sig. $=0.762$ (both $>0.05)$, this means that the regression model is linear. Thus, hypothesis testing with correlation and regression analysis can be continued. 
Table 3. Table of Linearity Test Results $\mathrm{X}_{1}$ Against Y Partially

\begin{tabular}{|c|c|c|c|c|c|c|c|}
\hline \multicolumn{8}{|c|}{ ANOVA Table } \\
\hline & & & $\begin{array}{l}\text { Sum of } \\
\text { Squares }\end{array}$ & df & $\begin{array}{l}\text { Mean } \\
\text { Square }\end{array}$ & $\mathrm{F}$ & Sig. \\
\hline \multirow{6}{*}{$\begin{array}{l}\text { Kemampuan } \\
\text { Guru Menyusun } \\
\text { Soal HOTS * } \\
\text { Supervisi oleh } \\
\text { Pengawas }\end{array}$} & Between & (Combined) & 13.262 & 21 & .632 & .324 & .982 \\
\hline & Groups & Linearity & .239 & 1 & .239 & .123 & .735 \\
\hline & & Deviation from & 13.023 & 20 & .651 & .334 & .978 \\
\hline & & Linearity & & & & & \\
\hline & Within Gr & & 15.578 & 8 & 1.947 & & \\
\hline & Total & & 28.840 & 29 & & & \\
\hline
\end{tabular}

Table 4. Table of Test Results for Linearity $\mathrm{X}_{2}$ Against Y Partially

\begin{tabular}{|c|c|c|c|c|c|c|c|}
\hline \multicolumn{8}{|c|}{ ANOVA Table } \\
\hline & & & $\begin{array}{c}\text { Sum of } \\
\text { Squares }\end{array}$ & $\mathrm{df}$ & $\begin{array}{l}\text { Mean } \\
\text { Square }\end{array}$ & $\mathrm{F}$ & Sig. \\
\hline \multirow{6}{*}{$\begin{array}{l}\text { Kemampuan } \\
\text { Guru Menyusun } \\
\text { Soal HOTS * } \\
\text { Supervisi oleh } \\
\text { Kepala Sekolah }\end{array}$} & Between & (Combined) & 14.893 & 18 & .827 & .653 & .797 \\
\hline & Groups & Linearity & .013 & 1 & .013 & .010 & .922 \\
\hline & & Deviation from & 14.880 & 17 & .875 & .690 & .762 \\
\hline & & Linearity & & & & & \\
\hline & \multicolumn{2}{|c|}{ Within Groups } & 13.947 & 11 & 1.268 & & \\
\hline & \multicolumn{2}{|l|}{ Total } & 28.840 & 29 & & & \\
\hline
\end{tabular}

\subsection{Significant Test Results}

Based on the results of the output of SPSS, the correlation coefficient between the variable of academic supervision by the supervisor $\left(\mathrm{X}_{1}\right)$ and the teacher's ability to compile HOTS items (Y) is 0.091 which is significant at 0.632 . The correlation coefficient value of 0.091 indicates a weak relationship between $\mathrm{X}_{1}$ and $\mathrm{Y}$ variables, so it can be concluded that there is no significant relationship between the academic supervision variable by the supervisor $\left(\mathrm{X}_{1}\right)$ and the teacher's ability variable in compiling HOTS (Y) items because the significance is $0.632>0.05$.

Furthermore, the correlation coefficient between the variable of academic supervision by the principal $\left(\mathrm{X}_{2}\right)$ and the variable of the teacher's ability to compose HOTS items $(\mathrm{Y})$ is 0.021 which is significant at 0.912 . The correlation coefficient value of 0.021 indicates the weak relationship between $\mathrm{X}_{2}$ and $\mathrm{Y}$ variables. In addition, the Sig. $0.912>0.05$ means that the correlation is not significant, so it can be concluded that there is no significant relationship between the school principal's academic supervision variable $\left(\mathrm{X}_{2}\right)$ and the teacher's ability variable in compiling HOTS items (Y).

Multiple correlation test aims to determine the relationship between variable $X_{1}$ and variable $X_{2}$ simultaneously to variable Y.Based on the results of the SPSS output, it is found that multiple correlation coefficient $(\mathrm{R})$ is 0.010 , which means that the relationship between the dependent variable and the independent variable is weak because $\mathrm{R}$ is smaller of 0.5 and $F$ count of 0.131 which is significant at 0.878 which is greater than the significance level of 0.05 $(5 \%)$. That is, the dependent variable does not have a significant relationship to the independent variable together

\subsection{Result of the coefficient of determination}

Based on the calculation results obtained $\mathrm{R} 2$ value (coefficient of determination) of 0.010 (1\%). The conclusion is that the variation of the teacher's ability variable in compiling HOTS items can be explained through the variable of academic supervision by the supervisor and the variable of academic supervision by the principal is only $1 \%$, the remaining $99 \%$ is influenced by other variables outside the research variables.

Based on the results of the analysis of the research findings, it can be found that the relationship of academic supervision by supervisors and principals together does not have a significant effect on the ability of teachers to compile HOTS items. The closeness of relationship together between the dependent variable and the independent variable is weak because $\mathrm{R}$ is less than 0.5. Therefore, based on the interpreted findings, 
it shows that in this study the ability of a biology teacher in designing HOTS items is not influenced by academic supervision by supervisors or by the principal $(1 \%)$, but is influenced by other variables (99\%).

Some of the factors are suspected of being related to the participatory nature of both supervisors and school principals found by researchers through respondents' responses, namely that the category is not yet active to supervise the teacher's ability to compile HOTS items, then the alleged subjectivity between teachers and school principals and supervisors is taking That is, the distribution of sample areas is only carried out within the scope of the South Tangerang City area so that there is not enough data to describe the provincial and national scale data, so there are many things that need to be further investigated.

\section{CONCLUSION}

Academic supervision by supervisors does not have a significant relationship with the teacher's ability to compile HOTS items. These findings indicate that the contribution of academic supervision carried out by supervisors to increasing the ability of teachers in their schools in composing HOTS items is low because the teacher's ability is more influenced by other variables.

Academic supervision by the principal also did not have a significant relationship with the teacher's ability to design HOTS items. Similar to the results in point number one, the contribution of academic supervision by the principal to the ability of teachers in his school to design HOTS items is very small. This also shows that there needs to be further research on other variables that contribute more to the ability of teachers to design HOTS items.

Furthermore, the results of multiple regression analysis show that all independent variables, namely academic supervision by the supervisor $\left(\mathrm{X}_{1}\right)$ and academic supervision by the principal $\left(\mathrm{X}_{2}\right)$, do not have a significant relationship with the teacher's ability to design HOTS items. These findings concluded that the academic supervision carried out by supervisors and school principals did not significantly contribute to the ability of teachers in their schools to design HOTS items.

\section{REFERENCES}

[1] Ahiri, J., Dunifa, L., Tanduklangi, A., Rahman, A., \& Ghani, A. (2013). The Effect of Learning Strategies on Higher-Order Thinking Skills Students with Different Learning Styles. International Journal of Science and Research (IJSR) ISSN (Online Index Copernicus Value Impact Factor, 14(9), 2319-7064.

[2] Astuti, S. (2017). Supervisi Akademik Untuk Meningkatkan Kompetensi Guru di SD Laboratorium UKSW. Scholaria, 7(1), 49-59.

[3] Burhendi, F. C. A., Wahyu Dian, L., Kusdiwelirawan, A., \& Sagita, D. D. (2019). Implementation of blended learning to use discovery learning method. International Journal of Innovation, Creativity and Change, 5(6), 153-163.

[4] Dian, D., \& Prayoga, A. (2019). Supervisi Akademik Kepala Madrasah di Madrasah Aliyah Darussalam Sumedang. BRILIANT: Jurnal Riset Dan Konseptual, 4(4), 548-558. https://doi.org/10.28926/briliant.v

[5] Dinni, H. N. (2018). HOTS ( High Order Thinking Skills ) dan Kaitannya dengan Kemampuan Literasi Matematika. Prisma, Prosiding Seminar Nasional Matematika, 1, 170-176.

[6] Hardono, Haryono, \& Yusuf, A. (2017). Kepemimpinan Kepala Sekolah, Supervisi Akademik, dan Motivasi Kerja dalam Meningkatkan Kinerja Guru. Educational Management, $\quad 6(1), \quad$ 26-33. http://journal.unnes.ac.id/sju/index.php/eduma $\mathrm{n}$

[7] Haryati, M. (2020). Analisis Soal UN Biologi SMA/MA Berdasar Dimensi Proses Kognitif, Karakteristik HOTS, Dan Bentuk Stimulus. Jurnal Education and Development, 8(2), 9194.

[8] Hidayati, A. U. (2017). TERAMPIL Jurnal Pendidikan dan Pembelajaran Dasar Volume 4 Nomor Melatih Keterampilan Berpikir Tingkat Tinggi dalam Pembelajaran Matematika Pada Siswa Sekolah Dasar. Pendidikan Dan Pebelajaran Dasar, 4(20), 143-156.

[9] Pratiwi, T. K., Akbar, B., \& Amirullah, G. 
(2017). Perbedaan Kemampuan Berpikir Tingkat Tinggi Siswa SMA Negeri 6 Tangerang dan SMA YUPPENTEK 1 Tangerang pada Mata Pelajaran Biologi. Jurnal Penelitian Mahasiswa Pendidikan Biologi, 2(1), $1-7$. http://pasca.um.ac.id/conferences/index.php/ip a2017/article/view/1046/716

[10] Sari, S. I., Ngaba, A. L., Lalupanda, E. M., \& Prastyo Aji, A. G. (2017). Pengendalian Dan Penjaminan Mutu Pengajaran Melalui Supervisi Klinis. Satya Widya, 33(1), 1. https://doi.org/10.24246/j.sw.2017.v33.i1.p110

[11] Sola, E. (2018). Ada Apa Dengan Supervisi Pendidikan? Idaarah: Jurnal Manajemen Pendidikan, 2(1), 130-140. https://doi.org/10.24252/idaarah.v2i1.5406

[12] Sulistiawati. (2019). Peningkatan Kemampuan Penyelesaian Soal Ujian Nasional Berorientasi
Higher Order Thinking Skill (HOTS) Melalui Pelatihan Pengembangan Soal HOTS Bagi Guru Matematika SMP. Seminar Nasional Penelitian Pendidikan Matematika (SNP2M), 2009, 180-189.

[13] Sumaryanta. (2018). Penilaian HOTS dalam Pembelajaran Matematika. Indonesia Digital Journal of Mathematics and Education, 8(8), 500-509.

[14] Suwartini, E. A. (2017). Supervisi Akademik Kepala Sekolah, Profesionalisme Guru Dan Mutu Pendidikan. Jurnal Administrasi Pendidikan, 24(2), 62-70.

[15] Yuliandini, N., Hamdu, G., \& Respati, R. (2019). Pengembangan Soal Tes Berbasis Higher Order Thinking Skill (HOTS) Taksonomi Bloom Revisi di Sekolah Dasar. PEDADIDAKTIKA: Jurnal Ilmiah Pendidikan Guru Sekolah Dasar, 6(1), 37-46. 